\title{
The Influence of Corporate Social Responsibility and Stakeholder Commitment to Company Performance with Slack Resources as Moderation
}

\author{
Wuryan Andayani ${ }^{1,{ }^{*}}$ Adel Hikam Arif ${ }^{2}$, Maharani Wuryantoro ${ }^{3}$ \\ ${ }^{1,2,3}$ Brawijaya University, Indonesia \\ *Corresponding author. Email: andayani@ub.ac.id
}

\begin{abstract}
This study aims to examine The Influence of CSR and Stakeholder Commitment on Firm performance with Slack Resources as Moderation. This research's contribution is that companies carry out philanthropy to communities affected by Covid19, and companies with excess resources can help people affected by Covid19. This study offers analysis method using PLS. We find that companies make every effort to make stakeholders believe that the company pays attention to social and environmental aspects. The slack resource has a direct effect to firm performance. Stakeholder commitment increases the disclosure of the company's financial performance. In CSR programs, companies can set aside profits to do philanthropy to empower communities, improve environmental damage, and carry out philanthropy to communities affected by the Covid-19 pandemic. The availability of company resources can improve the relationship between stakeholder commitment and company financial performance. The company uses resources to deal with unexpected conditions both internally and externally. Companies with excess resources can do philanthropy to help people affected by Covid19.
\end{abstract}

Keywords: CSR, Stakeholder, Firm Performance, Slack Resources, Covid-19.

\section{INTRODUCTION}

CSR implementation is still a debate among academics regarding whether it is a must for companies to implement CSR. The question among academics is whether companies that operate ethically and have a social responsibility are able to achieve better performance than companies that do not operate ethically. CSR is considered a reaction to pressure from stakeholders that can hinder company activities [1].

Various studies show that companies can take advantage of their ethically responsible operations and pay attention to social interests [1]. [2] suggests that some researchers state that management must always direct the company's operations only for the sake of increasing shareholder wealth. Companies must be socially responsible, get support from various stakeholders, and increase shareholder wealth while maintaining performance by carrying out ethically and socially responsible [3], [4].

Slack resources Companies need to maintain their good name by disclosing information on CSR implementation to the public with regard to their concern for environmental aspects, labour, consumers, society, and the energy used in company operations to gain the trust of shareholders and stakeholders which will lead to company performance [5].

[6], [7] show a negative relationship between CSR and company performance. According to [8], it is caused by managers who do not have the necessary capabilities to carry out CSR. [9] shows that CSR activities cannot always provide a higher company value but can provide a positive company value. [10] shows that donations given by companies have no effect on performance.

Companies cannot break away from their relationship with stakeholders [11]. According to [12], stakeholder orientation is a strategy to satisfy stakeholders for the company's sustainability. The implementation of CSR is an effort to maintain the company's commitment to stakeholders [13].

Slack resources are unutilized or surplus resources used to produce output [14]. Research 
conducted by [15], [16] shows a positive effect. This is in line with companies to carry out social actions. According to [17], slack resources represented by available slack and absorbed slack positively affect the company's performance. In addition, a metaanalysis conducted by [18] shows that there is a positive relationship.

The discussion about the effect of CSR on company performance shifts from the question "does it pay to be good" to "when does it pay to be good" [19]. In a meta-analysis conducted by [20], there are several moderators, for example, research conducted by [21] which uses industry as a moderator, and [22] uses innovation as a moderator.

The use of slack resources as a moderator was carried out in the research of [1]. According to [18], the role of the moderator for slack resources depends on the measuring instrument used and the performance measurement chosen. No research uses slack resources as a moderator of the relationship between CSR and company performance. This study filled the gap of the previous research.

\section{LITERATURE REVIEW}

\section{1. $C S R$}

[23] It stated that CSR is defined as the activity of carrying out social and environmental actions based on statutory regulations. The definitions by [24] include promoting economic prosperity, environmental improvement, social responsibility.

Disclosure of CSR information consists of a standalone report, assurance and reporting guideline to improve disclosure quality. Stand-alone reports prioritize social and environmental information aimed at stakeholders [25], [26], [27]. Assurance services aim to increase the credibility of CSR reporting [27], [28], [29], [30], [31]. The CSR implementation include social, environmental, ethical, human rights, and consumer concerns in their strategic plans [32]. Companies are always required to comply with government regulations and need to have voluntary initiatives to meet stakeholder expectations.

[6] states that CSR is designed to increase profits. Managers only have to be responsible to shareholders and carry out a fiduciary duty to maximize shareholder wealth. [11] refutes this argument by stating that companies must consider the differences in needs between individuals and groups that can affect the company or be affected by the company's activities. Companies have to relate well to stakeholders is the main key to the CSR program. The perspective of stakeholders is a strategic tool in business strategy management [33].

\subsection{Resource Based Theory and Slack Resources}

This study uses RBV as a basis that the company collects various resources [34]. Owned resources are unique and cannot be duplicated by other companies [35]. According to RBV, the resources owned by the company enable the company to operate more effectively and efficiently [36]. Resources owned by a company can be categorized into financial, physical, legal, human resources, organizational, informational, or relational [36].

Slack resources itself is exceeds the minimum requirement to produce output [14]. These resources can include excess inputs such as labor that is not working at full capacity or excess financial resources [37]. [38] define slack resources as a kind of backing that allows companies to adapt to external and internal pressures caused by environmental changes or institutional changes.

Regarding slack measurement, financial-based measurements are very commonly used, such as changes in budget and sources of funds [39], or changes in expenses for company operations [40]. [41], measure both financial slack and human resource slack. Available slack includes cash and financial instruments available as financial resources in the future [42]. Potential slack is a discretion that can indicate future resources from external parties through debt and investment [42].

\subsection{CSR, Slack Resources, and Company Performance}

Previous studies have shown that CSR has a positive effect on performance because it can provide easy access to important resources [43], makes it easier for companies to promote products [44] and helps companies gain legitimacy from stakeholders [45].

CSR is used as a company tactic to signal to the public about the company's attitude towards society to build good relationships, which will also lead to performance [46]. Thus, hypothesis 1 is derived as follows: 
H1: There is a positive relationship between CSR and Company Financial Performances

[47] It shows that the higher the company's slack resources, the more companies invest in CSR. [15] [16] show the positive influence of slack resources on CSR because slack resources become an opportunity for companies to take social actions. [17] Stated slack resources as measured by indicators of available slack and absorbed slack have a positive effect on the company's market performance. [18] It shows that slack resources affect company performance depending on the slack and performance indicators used. Slack resources affect CSR and performance, the hypothesis proposed is:

H2: Slack Resources moderates the relationship between CSR and Performance.

\subsection{Stakeholder Theory}

Stakeholder theory states that companies must consider the interests of the company's stakeholders [48] and have a responsibility to operate in the interests of all stakeholders [11]. Company management will take stakeholders into account and focus on specific stakeholders for the sustainability of the company's life [49]. Disproportionate attention to stakeholders can help companies gain legitimacy to get better financial performance [50]. The company needs to consider stakeholders' aspirations and demands and the possible impact of each policy taken and take corrective action [51]. Companies that want to be successful in the long term can meet stakeholder demands [11]. [52] states that there are two stakeholder groups, namely primary and secondary stakeholders.

H3: There is a positive relationship between stakeholder commitment and disclosure of the company's financial performance

H4: Slack resources moderate the relationship between stakeholder commitment and corporate financial performance.

\subsection{Conceptual Framework}

Figure 1 illustrates the conceptual framework based on resource-based theory, stakeholder theory, the relationship between CSR and stakeholder commitment with the company's financial performance, and the moderating variable of slack resources.

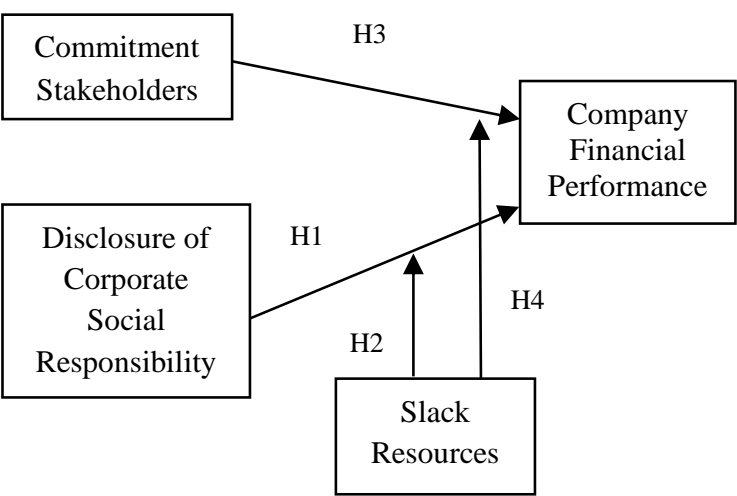

Figure 1 Conceptual Framework

\section{RESEARCH METHODS}

\subsection{Research Data}

Research data is taken from public companies listed on the Indonesia Stock Exchange from 2014 to 2018.

\subsection{Research Samples}

The research sample is as divided into 4 (four) criteria that are (1) population, issuers are no longer listed on the IDX during the observation period, (2) issuers do not disclose social and environmental information for 5 consecutive years, (3) either in annual reports or in sustainability reports, and (4) the number of samples that meet the criteria. Besides that, the total sample as much as 350 sample with object of research is 70 .

\subsection{Independent Variable}

\subsubsection{The Independent Variable}

\subsubsection{Stakeholders}

Stakeholder commitment measured using the four-item measures disclosed in this category, namely 1). List of stakeholder groups involved by the organization, 2). The basis used in identifying and selecting stakeholders, 3). Approach to stakeholder engagement, 4). Stakeholder engagement topics.

\subsubsection{CSR, Namely the Quality of CSR Disclosure}

The quality variable of CSR is measured using a measurement model designed by [53]. The 
information measures the quality of CSR disclosure disclosed (relative quantity), information density, information accuracy, and management orientation.

\subsubsection{Slack Resources}

Slack resources are the excess of actual and potential resources owned by the company [38]. These resources adapt according to changing conditions of the company's internal pressure and external pressure. Slack resources are measured using Current Ratio and Debt to Equity proxies.

\subsection{Dependent Variable}

\subsubsection{Financial Performance}

ROA, ROE and TobinQ measure financial performance variables as market-based performance measures [54]. High ROA indicates that the company has higher wealth.

$R O A=$ Net Profit Before Tax/Total Asset

ROE is calculated by the formula:

ROE $=\frac{\text { Net Profit After Tax }}{\text { Equity }} \times 100 \%$

TobinQ is a performance measure concerning investment opportunities. Tobin $\mathrm{Q}$, which is more than 1 indicates that the market value of the company's assets is greater than its replacement cost. TobinQ is calculated by:

$$
\text { TobinQ }=\frac{M V E+P S+D E B T}{\text { Total Aset }}
$$

\subsection{Analysis Method}

To test the hypothesis proposed use PLS. PLS is appropriate to test the predictive effect of the relationship between latent variables in a model that does not require normally distributed data, and can combine regression and factor analysis methods in one statistical technique.

\section{RESULTS AND DISCUSSION}

\subsection{Results of Partial Least Square (PLS)}

\subsubsection{Analysis Initial Validity and Reliability Test}

There are two types of validity in PLS SEM: convergent validity and discriminant validity. The Average Variance Extracted (AVE) value is at least 0.5 . This value illustrates adequate convergent validity, which means that one latent variable is able to explain more than half the variance of its indicators on average.

The reliability of the measurement model is tested through the value of Cronbach's alpha and composite reliability (CR) which must reach a minimum of more than 0.7 so that the research instrument can be said to be reliable.

Table 1. Validity and Reliability Test

\begin{tabular}{|l|c|c|c|c|}
\hline & Cronbach's Alpha & rho_A & CR & AVE \\
\hline Performance & 0,812 & 0,952 & 0,877 & 0,712 \\
\hline $\begin{array}{l}\text { Stakeholders } \\
\text { Commitment }\end{array}$ & 1,000 & 1,000 & 1,000 & 1,000 \\
\hline CSR Disclosure & 1,000 & 1,000 & 1,000 & 1,000 \\
\hline Size & 1,000 & 1,000 & 1,000 & 1,000 \\
\hline Slack Resources & 0,265 & 0,534 & 0,580 & 0,348 \\
\hline Age & 1,000 & 1,000 & 1,000 & 1,000 \\
\hline
\end{tabular}

The analysis shows that the Average Variance Extracted on the slack variable shows the number 0.348 which means it has not met convergent validity. Cronbach alpha value in the slack variable shows the number 0.265 which is not reliable because less than 0.7 (table 2). Therefore, indicators with an outer loading value of less than 0.5 or 0.7 should be eliminated. 
Table 2. Outer Loading

\begin{tabular}{|c|c|c|c|c|c|c|}
\hline & Performance & $\begin{array}{l}\text { Stakeholders } \\
\text { commitment }\end{array}$ & CSR Disclosure & Size & Slack & Age \\
\hline Absorbed Slack & & & & & 0,328 & \\
\hline Age & & & & & & 1,000 \\
\hline Available Slack & & & & & 0,486 & \\
\hline Current Ratio & & & & & 0,818 & \\
\hline Debt to Equity Ratio & & & & & 0,796 & \\
\hline Financial Slack & & & & & $-0,306$ & \\
\hline $\begin{array}{l}\text { Stakeholders } \\
\text { Commitment }\end{array}$ & & 1,000 & & & & \\
\hline CSR Disclosure & & & 1,000 & & & \\
\hline ROA & 0,950 & & & & & \\
\hline ROE & 0,598 & & & & & \\
\hline Size & & & & 1,000 & & \\
\hline TobinQ & 0,937 & & & & & \\
\hline
\end{tabular}

The outer loading value of absorbed slack, available slack and financial slack are $0.328,0.486$, and -0.306 , respectively, which is invalid because less than 0.5. Therefore, these indicators should be eliminated.

Following the elimination of absorbed slack, available slack and financial slack, none of the Average Variance Extracted values for all variables is less than 0.5, which means the instrument meets convergent validity (Table 2). According to the Fornell-Larcker criteria, the cross-loading value of each indicator is greater than the other indicators to fulfill the discriminant validity (Table 3). The Cronbach alpha value for each variable shows several more than 0.7 , which means that the instrument used in this study is consistent.

Table 3. Second Validity and Reliability Test Result

\begin{tabular}{|l|c|c|c|c|}
\hline & Cronbach's Alpha & rho_A & CR & AVE \\
\hline Performance & 0,812 & 0,948 & 0,873 & 0,706 \\
\hline $\begin{array}{l}\text { Stakeholders } \\
\text { Commitment }\end{array}$ & 1,000 & 1,000 & 1,000 & 1,000 \\
\hline CSR Disclosure & 1,000 & 1,000 & 1,000 & 1,000 \\
\hline Size & 1,000 & 1,000 & 1,000 & 1,000 \\
\hline Slack Resources & 0,759 & 0,769 & 0,892 & 0,805 \\
\hline Age & 1,000 & 1,000 & 1,000 & 1,000 \\
\hline
\end{tabular}

Table 4. Fornell-Larcker Criterion

\begin{tabular}{|l|c|c|c|c|c|c|}
\hline & Performance & $\begin{array}{c}\text { Stakeholders } \\
\text { commitment }\end{array}$ & CSR Disclosure & Size & Slack & Age \\
\hline Performance & 0,840 & & & & & \\
\hline $\begin{array}{l}\text { Stakeholders } \\
\text { commitment }\end{array}$ & 0,371 & 1,000 & & & & \\
\hline CSR Disclosure & 0,052 & 0,029 & 1,000 & & & \\
\hline Size & $-0,035$ & 0,366 & $-0,064$ & 1,000 & & \\
\hline Slack & 0,397 & 0,233 & 0,009 & $-0,212$ & 0,897 & \\
\hline Age & 0,312 & 0,412 & $-0,033$ & 0,331 & 0,088 & 1,000 \\
\hline
\end{tabular}




\subsection{Hypothesis Testing}

Analysis shows that CSR disclosure has no significant effect on performance and slack resources does not moderate the relationship between CSR disclosure and performance as p-value exceed 0,05 $(0,522$ and 0,759$)$. Thus, $\mathrm{H} 1$ and $\mathrm{H} 2$ are rejected. This result supports [53] work suggesting that CSR disclosure is no more than symbolic action. Apart from that, CSR disclosure is also nothing more than a way for firms to gain legitimacy [55].

H3 is accepted, it means that stakeholder commitment increases the disclosure of the company's financial performance. CSR is the moral responsibility of the company to stakeholders. In CSR programs companies can set aside profits to do philanthropy to empower communities and make repairs to environmental damage. The company carries out philanthropy to communities affected by the Covid-19 pandemic. H4 is accepted, it means that the availability of company resources can improve the relationship between stakeholder commitment and company financial performance. The availability of resources is used by the company to deal with unexpected conditions both internally and externally [38]. Thus, companies that have excess resources can do philanthropy to help people affected by Covid19.

Table 5. Path Analysis

\begin{tabular}{|l|c|c|c|c|c|c|}
\hline & $\begin{array}{c}\text { Original } \\
\text { Sample (O) }\end{array}$ & $\begin{array}{c}\text { Sample } \\
\text { Mean (M) }\end{array}$ & $\begin{array}{c}\text { Standard } \\
\text { Deviation } \\
\text { (STDEV) }\end{array}$ & $\begin{array}{c}\text { T Statistics } \\
(\mid \text { O/STDEV|) }\end{array}$ & P Values & Notes \\
\hline $\begin{array}{l}\text { CSR Disclosure -> } \\
\text { Performance }\end{array}$ & 0,035 & 0,041 & 0,018 & 1,939 & 0,053 & H1 Rejected \\
\hline $\begin{array}{l}\text { Moderator 1 } \\
\text { CSR Disclosure- } \\
\text { Slack Resources -> } \\
\text { Performance }\end{array}$ & $-0,027$ & $-0,033$ & 0,229 & 0,117 & 0,907 & H2 Rejected \\
\hline $\begin{array}{l}\text { Stakeholder } \\
\text { Commitment -> } \\
\text { Performance }\end{array}$ & 0,257 & 0,255 & 0,062 & 4,169 & 0,000 & H3 Accepted \\
\hline $\begin{array}{l}\text { Moderator } \\
\text { Stakeholder } \\
\text { Commitment - } \\
\text { Slack Resources -> } \\
\text { Performance }\end{array}$ & 0,120 & 0,120 & 0,042 & 2,859 & 0,004 & H4 Accepted \\
\hline $\begin{array}{l}\text { Slack Resources -> } \\
\text { Performance }\end{array}$ & 0,183 & 0,189 & 0,062 & 2,923 & 0,004 & \\
\hline Size -> Performance & $-0,159$ & $-0,149$ & 0,044 & 3,617 & 0,000 & \\
\hline Age -> Performance & 0,225 & 0,224 & 0,045 & 4,990 & 0,000 & \\
\hline
\end{tabular}

\section{CONCLUSION}

The results of this study indicate that CSR disclosure has no effect on firm performance and slack resources does not moderate the relationship between them. This is because CSR disclosure, in practice, is a firm effort to gain legitimacy. Firms carry out CSR disclosures only as symbolic, in order to get a positive impression so that they can improve the firm's image as well as gain legitimacy from stakeholders. This finding is consistent with [60] work.

Stakeholder commitment increases the disclosure of the company's financial performance. CSR is the moral responsibility of the company to stakeholders.
In CSR programs companies can set aside profits to do philanthropy to empower communities and make repairs to environmental damage. The company carries out philanthropy to communities affected by the Covid-19 pandemic and companies that have excess resources can do philanthropy to help people affected by Covid19.

\section{REFERENCES}

[1] Lin, W. L., Ho, J. A., Ng, S. I., \& Lee, C, Does corporate social responsibility lead to improved firm performance? The hidden role of financial slack. Social Responsibility Journal, 2019. 
[2] Freedman, M, Capitalism and Freedom. Chicago: University of Chicago press., 2009

[3] Flammer, C, Corporate social responsibility and shareholder reaction: the environmental awareness of investors. Academy of Management Journal, vol. 56, 3, 2013, pp. 758781 .

[4] Wang, Q., Dou, J., \& Jia, S, A Meta-Analytic Review of Corporate Social Responsibility and Corporate Financial Performance: The Moderating Effect of Contextual Factors. Business and Society, 2016, pp. 1-39.

[5] Andayani, W., \& Daud, D, The Effect Of Corporate Governance Structure On Financial Difficulties, Entrepreneurship And Sustainibility Issues, vol 7, 3, 2020, pp. 1803-1817.

[6] Friedman, M, A theoretical framework for monetary analysis. Journal of Political Economy, vol 78, 2, 1970, pp. 193-238.

[7] Crisóstomo, V. L., Freire, F. d., \& Vasconcellos, F. C, Corporate social responsibility, firm value and financial performance in Brazil. Social Responsibility Journal, vol. 7 issue 2, 2011, pp. 295-309.

[8] Pacheco-de-Almeida, G., \& Zemsky, P, The Timing of Resource Development and Sustainable Competitive Advantage. Management Science, vol. 53, no. 4, 2007, pp. $651-666$.

[9] Kim, W. S., \& Oh, S, Corporate social responsibility, business groups and financial performance: a study of listed Indian firms. Economic Research-Ekonomska Istrazivanja, vol $32,1,2019$, pp. 1777-1793.

[10] Seifert, B., Morris, S. A., \& Bartkus, B. R, Having, Giving, and Getting: Slack Resources, Corporate Philanthropy, and Firm Financial Performance. Business Society 43, 135, 2004, pp. 135-161.

[11] Freeman, E. R, Strategic Management: A Stakeholder Approach. Boston: Pitman, 1984.

[12] Barney, J, Firm Resources and Sustained Competitive Advantage. Journal of Management, vol. 17, 1, 1991, pp. 99-120.

[13] Freeman, E., \& Dmytriyev, S, Corporate Social Responsibility and Stakeholder Theory: Learning from Each Other. SYMPHONYA Emerging Issues in Management, 1, 2017.
[14] Nohria, N., \& Gulati, R, Is Slack Good or Bad for Innovation? The Academy of Management Journal, vol. 39, 5, 1996, pp. 1245-1264.

[15] Zhang, Y., Li, J., Jiang, W., Zhang, H., Hu, Y., \& Liu, M, Organizational structure, slack resources and sustainable corporate socially responsible performance. Corporate Social Responsibility Environment Management, 2018, pp. 1-9.

[16] Melo, T, Determinants of corporate social performance: the influence of organizational culture, management tenure and financial performance. Social Responsibility Journal, vol. 8 issue 1, 2012, pp. 33-47.

[17] Mattingly, J. E., \& Olsen, L, Performance Outcomes of Investing Slack Resources in Corporate Social Responsibility. Journal of Leadership and Organisational Studies, 2018, pp. $1-18$.

[18] Agusti-Perez, M., Galan, J. L., \& Acedo, F. J., Relationship between slack resources and performance: temporal symmetry and duration of effects, European Journal of Management and Business Economics, 2020.

[19] Orlitzky, M., Siegel, D., \& Waldman, D, Strategic Corporate Social Responsibility and Environmental Sustainability. Business and Society, vol. 50 issue 1, 2011, pp. 6-27.

[20] Grewatsch, S., \& Kleininst, I, When Does It Pay to be Good? Moderators and Mediators in the Corporate Sustainability-Corporate Financial Performance Relationship: A Critical Review. Journal of Business Ethics 145(2), 2015, pp. 384416.

[21] Baird, P. L., Geylani, P. C., \& Roberts, J. A, Corporate Social and Financial Performance ReExamined: Industry Effects in a Linear Mixed Model Analysis, Journal of Business Ethics, vol. 109, 2012, pp. 367-388.

[22] Hull, C. E., \& Rothenberg, S, Firm performance: the interactions of corporate social performance with innovation and industry differentiation. Strategic Management Journal, vol. 29 issue 7, 2008, pp. 781-789.

[23] Chambers. E, Corporate Social Responsibility and Environmental Management, United Kingdom: Nottingham University, 2003. 
[24] Nature, The Problematic of Sustainable Development and Corporate Social Responsibility, New Jersery, USA, 2001.

[25] Dhaliwal, D. S., S. Radhakrishman, A. Tsang, and Y. G. Yang, Nonfinancial Disclosure and Analyst Forecast Accuracy: International Evidence on Corporate Social Responsibility Disclosure. The Accounting Review 87, 3, 2012, pp. 723-759.

[26] Dhaliwal, D. S., Li, O. Z., Tsang, A., \& Yang, Y. G, Corporate Social Responsibility Disclosure and the Cost of Equity Capital: The Roles of Stakeholder Orientation and Financial Transparency, Journal of Accounting and Public Policy, 2014.

[27] Anugerah, Eza Gusti, Erwin Saraswati, Wuryan Andayani, Quality of Disclosure and Corporate Social Responsibility Reporting Practices in Indonesia, Jurnal Akuntansi, vol. XXII, 03, September, 2018, pp. 337-353.

[28] Wong, R., \& Millington, A, Corporate Social Disclosures: A User Perspective on Assurance, Accounting, Auditing \& Accountability Journal, 27(5), 2014, pp. 863-887.

[29] Casey, R. J., \& Grenier, J. H, Understanding and Contributing to the Enigma of Corporate Social Responsibility (CSR) Assurance in the United States, Auditing: A Journal of Practice and Theory, 34, 1, 2015, pp. 97-130.

[30] Cohen, J. R., \& Simnett, R, CSR and Assurance Services: A Research Agenda, Auditing: A Journal of Practice \& Theory, vol. 34(1), 2015, pp. 59-74.

[31] Habek, P., \& Wolniak, R, Relationship Between Management Practices and Quality of CSR Reports, Procedia - Social and Behavioral Sciences, 220, 2016, pp. 115-123.

[32] Commission of the European Communities, A renewed EU strategy 2011-14 for corporate social responsibility. Brussels: European Commission, 2011.

[33] Solomon, A., \& Lewis, L, Incentives and disincentives for corporate environmental disclosure. Business Strategy and the Environment, vol. 11 issue 3, 2002, pp. 154-169.

[34] Hodgson, G. M, The Approach of Institutional Economics. Journal of Economic Literature, vol. 36, no. 1,1998 , pp. 166-192.
[35] Branco, M. C., \& Rodrigues, L. L, Corporate Social Responsibility and Resource-Based Perspectives. Journal of Business Ethics, vol. 69, 2006, pp. 111-132.

[36] Hunt, S. D, A General Theory of Competition: Resources, Competences, Productivity, Economic Growth. CA: SAGE Publications, Inc, 2000.

[37] Tan, J, Curvilinear Relationship Between Organizational Slack and Firm Performance:: Evidence from Chinese State Enterprises. European Management Journal, vol. 21 issue 6, 2003, pp. 740-749.

[38] Bourgeois, L. J., \& Singh, J. V, Organizational Slack and Political Behavior Among Top Management Teams. Academy of Management, 1983, pp. 43-49.

[39] Aiken, M., \& Hage, J, The Organic Organization and Innovation. vol. 5, no. 1, 1971, pp. 63-82.

[40] Daft, R., \& Becker, S, Innovation in Organizations. New York: Elsevier, NorthHolland, Inc, 1978.

[41] Miller, D., \& Friesen, P. H, Innovation in conservative and entrepreneurial firms: Two models of strategic momentum. Strategic Management Journal, 3, 1982, pp. 1-25.

[42] Cheng, J. L., \& Kesner, I, Organizational slack and response to environmental shifts: The impact of resource allocation patterns. Journal of Management, 23(1), 1997, pp. 1-18.

[43] Usman, A. B., \& Amran, N. A, Corporate social responsibility practice and corporate financial performance: evidence from Nigeria companies. Social Responsibility Journal, vol. 11, 4, 2015, pp. 749-763.

[44] Fombrun, C. J., \& Rindova, V, Who's tops and who decides? The social construction of corporate reputations. New York University, Stern School of Business, Working Paper, 1993, pp. 5-13.

[45] Hawnk, O., Chatterji, A., \& Mitchell, W, Two coins in one purse? how market legitimacy affects the financial impact of changes in social legitimacy: addition and deletion by the dow jones sustainability index. Working paper, The Fuqua School of Business, Duke University, 2011. 
[46] Porter, M.E. and Kramer, M.R, Strategy \& Society: The Link between Competitive Advantage and Corporate Social Responsibility. Harvard Business Review, 84, 2006, pp. 78-85.

[47] Harrison, J. S. and J. E. Coombs, The Moderating Effects from Corporate Governance Characteristics on the Relationship Between Available Slack and Community-Based Firm Performance. Journal of Business Ethics, 107 (4), 2012, pp. 409-422.

[48] Donaldson, Thomas and Lee E Preston, The Stakeholder Theory of the Corporation: Concepts, Evidence and Implications. The Academy of Management Review, vol. 20, 1 (January), 1995, pp. 65-91.

[49] Mitchell, Ronald; Bradley Agle; Donna J Wood, Towards a Theory of Stakeholder Identification and Salience: Defining the Principle of Who and What Really Counts. The Academy of Management Review, October, 1997.

[50] Pfarrer, Michael D; Katy Decelles; Ken G Smith, After the Fall: Reintegrating the Corrupt Organization. The Academy of Management Review, July 2008.
[51] Freeman, E, Strategic Management: A Stakeholder Approach. Cambridge: Cambridge University Press, 2010.

[52] Clarkson, Max B. E, A Stakeholder Framework for Analyzing and Evaluating Corporate Social Performance. The Academy of Management Review, vol. 20, no. 1, Jan, 1995, pp. 92-117.

[53] Michelon, Gionvanna; Silvia Pilonato; Federica Ricceri, CSR Reporting Practices and the quality of disclosure: An Empirical analysis. Critical Perspectives on Accounting. November 2014.

[54] Cheng, S., Lin, K. Z., \& Wong, W, Corporate social responsibility reporting and firm performance: evidence from China. Journal of Management and Governance, vol. 20, 2015, pp. 503-523.

[55] Cho, Yoon Jik and James L. Perry, Intrinsic Motivation and Employee Attitudes Role of Managerial Trustworthiness, Goal Directedness, and Extrinsic Reward Expectancy. Review of Public Personnel Administration. December 2012. 